\title{
Capital Investment Appraisal Practices in the Emerging Market Economy of Sri Lanka
}

\author{
Lingesiya Kengatharan* and Mohamed Nurullah
}

\begin{abstract}
Manuscript type: Research paper

Research aims: This study aims to investigate the prevalent choice of capital investment appraisal practices and the influence of firm characteristics on the choice of these practices.

Design/Methodology/Approach: A survey is conducted by using a sample of 186 Chief Financial Officers (CFOs) from companies listed on the Colombo Stock Exchange platform in Sri Lanka.

Research findings: This study reveals that the most popular capital investment appraisal techniques used in Sri Lanka encompass Net Present Value (NPV), followed by Internal Rate of Return (IRR), Payback (PB), Accounting Rate of Return (ARR) and Discounted Payback (DPB). As for the capital investment appraisal tools incorporating risks, Sri Lankan firms prefer uncertainty absorption in cash flows, followed by sensitivity analysis, probability analysis, scenario analysis, and adjusting the required returns. Emerging real options are used at the embryonic stage in Sri Lanka. The use of naive capital budgeting practices is mostly preferred by small firms managed mainly by CFOs with non-MBA educational qualifications with short tenures in the firms. In contrast, sophisticated and advanced capital budgeting practices are mostly used by large firms managed by MBA qualified CFOs with a long tenure in the firms. As for industry differences, ARR is primarily applied by non-MBA CFOs in most non-manufacturing firms. None of the other methods trigger any significant difference in terms of industry types.
\end{abstract}

\footnotetext{
* Corresponding author: Lingesiya Kengatharan is a Senior Lecturer at the Department of Financial Management, Faculty of Management Studies and Commerce, University of Jaffna, 40,000, Sri Lanka. Email: lingesiya@univ.jfn.ac.lk

Mohamed Nurullah is an Associate Professor at the Department of Accounting, Finance and Informatics, Kingston Business School, Faculty of Business and Law, Kingston University, Kingston Hill, Kingston Upon Thames, Surrey KT 27 LB, United Kingdom. Email: m.nurullah@kingston.ac.uk
}

https:// doi.org/10.22452/ajba.vol11no2.4 
Theoretical contributions/Originality: This study makes contextual contributions by providing evidence of the application of capital investment appraisal practices in an emerging market economy, namely Sri Lanka. This study also provides parametric contributions as it identifies the influence of firm characteristics on the choice of capital budgeting practices.

Practitioner/Policy implications: This study raises the awareness of top management, policy makers, practitioners and stakeholders of companies with regards to capital investment appraisal practices and the influence of firm characteristics on these practices.

Research limitations/Implications: A more detailed study encompassing other countries with a similar culture like Sri Lanka is beneficial for further validation, replication and generalisation. Future studies may also consider looking at the influence of behavioral factors in making capital budgeting choices.

Keywords: Capital Budgeting, Risk, Developing Countries

JEL Classification: G30, G31, G32

\section{Introduction}

Capital budgeting is a major terrain in the sphere of financial management. It is defined as a set of procedures, routines, methods and techniques used for making decisions on how to allocate resources among investment projects so that corporate profitability and the financial growth of a firm is ensured (Segelod, 1998; Al-Mutairi, Naser, \& Saeid, 2018). This is supported by the International Federations of Accountants (2013) which stated that to maintain a strong and sustainable economic growth, it is important for a firm to adopt a systematic, analytical and thorough investment appraisal approach that is sound in judgement. Considering the importance of capital budgeting, it is not surprising that this area of research has been a subject of growing theoretical and empirical interest among scholars (Al-Muthairi et al., 2018; Verma, Gupta, \& Batra, 2009; Segelod, 1998; Dixit \& Pindyck, 1994; Roll, 1977; Lintner, 1965; Sharpe, 1964).

The past six decades have generated much literature (e.g. Dixit \& Pindyck, 1994; Roll, 1977; Lintner, 1965; Sharpe, 1964) which emphasises on the many overarching theories and models that can be used to facilitate the process of identifying the best investment alternatives. Nonetheless, the applicability of such theories and models may no longer serve the current generation (Sangster, 1993; Slagmulder, Bruggeman, 
\& Wassenhove, 1995). This can be attributed to the global financial crisis, sustainable development goals, environmental uncertainty in the market, increased globalisation, shortened product lifecycles and the need for more customisation and cutting edge technological developments. These factors contribute to the new challenges that corporate financial management is experiencing today. They also impact the enormous changes happening in capital budgeting (Slagmulder et al., 1995; Verbeeten, 2006; Verma et al., 2009). This is endorsed by Meyer and Kiymaz (2015) who expected firms to give more weight to sustainability dimensions in their capital budgeting decisions by focussing more attention on the triple bottom line ipso facto. However, many renowned research scholars (e.g., Mao, 1970; de Andrés, de Fuente, \& San Martín, 2015) have noted that there are gaps in the theory of capital budgeting and its applicability. In the beginning of the new millennium (during the 2000s), researchers (Arnold \& Hatzopoulos, 2000) have foreseen that the capital budgeting theory is not going to be applicable for all times. Moreover, capital budgeting practices have not been static and many studies (Brounen, de Jong, \& Koedijik, 2004) have also diverged from the theories. It was further asserted that while concepts such as the capital asset pricing model have been largely taught in classrooms, the extent of it being practised in the corporate world is debatable. Arnold and Hatzopoulus (2000) stressed that uncertainty, information asymmetry, multiple objectives, real options and multi period project are also great concerns which further complicate capital budgeting decisions, beyond the focus of the theory. Consequently, literature (Kersyte, 2011; Mutairi, Tian, Hasan, \& Tan, 2012; de Andrés et al., 2015) emphasised that budgeting exercises give one the view that there is no unique correct technique. It was further mentioned that there is a need for multiple methods to be used in practices by incorporating risk and uncertainty with capital budgeting techniques. Highlighting the gap that exists between what is theoretically right and what is actually preferred in practice, de Andrés et al. (2015) has thus stressed that there is a need to have a more intensive approach in corporate finance literature, especially for the business environment. In this regard, it is important to investigate capital budgeting practices.

This study focuses on the application of capital investment appraisal/budgeting practices and the influence of firm characteristics on the choice of these practices within an emerging market, namely Sri Lanka. As a country experiencing robust economic growth since the end of its 30-year civil war, Sri Lanka has also shown a more 
sustainable growth since May 2009 onwards. The Central Bank of Sri Lanka (2017) has stated that all key sectors of the economy demonstrate a commendable performance for 2016 and 2017, establishing itself as a middle income economy. This result is possible due to Sri Lanka's peaceful domestic environment, improved investors' confidence, favourable conditions of macroeconomic factors, and the gradual recovery of the global economy. From being a country embedded in the deepest recession in history, Sri Lanka's economy is transitioning from a predominantly rural-based economy to one that is more urbanised, revolving around the manufacturing and service industries. According to the World Bank Group (2018), Sri Lanka has recorded an increase in gross domestic product (GDP) of 1.4 per cent in the fourth quarter of 2017, as compared to the same quarter in the previous year. It has also made significant progress in its economic growth in terms of socio-economic and human capital indicators. Sri Lanka was ranked among the highest in South East Asia in terms of social indicators, with its national poverty headcount ratio declining by approximately 10 per cent, from 2006 to 2016. Its stable economic environment has also attracted foreign interests for investment as supported by the report made by the Central Bank of Sri Lanka (2017), showing the highest ever inflows in 2017 supported by improving investor sentiments. Sri Lanka's positive economic development is expected to open up more international capital markets and to bring in more investors who are targeting emerging markets with strong projected growth. Presently, investment decisions play a more vital role than ever before in Sri Lanka. In the post war recovery phase, the ongoing reforms of the financial market had served as the fundamental factor which accelerated Sri Lanka's economic growth more than ever before. Greenberg (2013) stated that Sri Lanka's emerging economy is evidenced by the following: (1) In 2010, the Sri Lankan stock exchange posted an increase of 95 per cent for the year; (2) Sri Lanka has maintained itself as an important trade port linking Western Europe and Africa to Eastern Europe and Asia; (3) Sri Lanka has current investments in infrastructure such as roads, railroads and telecommunications; (4) Sri Lanka has a high level of literacy rate supported by its skilled/educated workforce and (5) Sri Lanka has a strong tourism sector. All of these are, evidently, an important part of being an emerging economy, hence, the reason why this study chose to focus on Sri Lanka.

In the literature (Koralalage \& Mudiyaselage, 2014; Nurullah \& Kengatharan, 2015; Pathirawasam, 2016) of capital budgeting practices, 
very few studies have looked at the terrain of capital budgeting over the last four decades within the country setting. While existing studies have provided some insights into the capital budgeting practices of Sri Lanka, these have been limited in scope, focusing mainly on the purpose of investment for capital budgeting, methods employed and their antecedent factors. In contrast, the current study aims to expand on previous studies by covering different aspects of capital budgeting practices employed by firms operating in different sectors of the economy. In this regard, the current study compares the results generated with those gained from previous empirical studies done in the US, Europe and India. It is hoped that this comparison can facilitate in filling in the research gaps in terms of contextual setting. Although capital budgeting theory appears to be applicable to all countries, to a certain extent, the actual practices of capital budgeting varies according to the "country effect" (Graham \& Harvey, 2001; Hermes, Smid \& Yao, 2007). Therefore, the findings of this study are expected to benefit both the academicians and practitioners. The results would assist academicians in terms of conducting future research and also in revising the curriculum adopted by business schools currently operating in Sri Lanka and similar emerging countries in terms of economic development. This study will also benefit practitioners by helping firms and organisations to make better investment decisions by using the right capital budgeting technique.

The rest of this paper is arranged as follows: Section 2 reviews the relevant literature on capital budgeting techniques. Section 3 explains the methodology employed. Section 4 presents the results and discussions. Section 5 concludes while Section 6 highlights the limitations and suggestions for future research.

\section{Literature Review}

\subsection{Prior Studies on Capital Budgeting}

Studies (e.g. Graham \& Harvey, 2001; Hermes et al., 2007) looking at capital budgeting can be classified into two main areas. The first area concerns capital budgeting techniques most frequently used in practice. For example, Babu and Sharma (1995) investigated 73 Indian companies. They found that Internal Rate of Return (IRR) and Payback (PB) were the most prevalent techniques used. This finding is found to be inconsistent with Singh, Jain and Yadav (2012), which is also based on Indian listed 
firms. Looking at 35 firms listed on the Karachi Stock Exchange, Zubairi (2008) highlighted that the techniques used depend very much on firm size. He further noted that bigger size firms were more inclined towards IRR while smaller firms preferred Net Present Value (NPV) and PB. From the perspectives of Western countries, Graham and Harvey (2001) found NPV and IRR to be the most popular methods, while Adjusted Present Value (APV) appeared to be the least used method in the US. This finding was consistent with Ryan and Ryan (2002). Other scholars like Brounen et al. (2004) attempted to make a comparative study. Looking at four European countries namely the UK, France, Germany and the Netherlands, Brounen et al. (2004) found differences in the capital budgeting technique used across the countries. While NPV and $\mathrm{PB}$ are more prevalent in the UK, Netherlands and Germany, France recorded lower usage on NPV methods.

Following the techniques, the second area of capital budgeting looks at the relationship between the use of capital budgeting techniques and firm attributes. Nishat and Haq (2009), for instance, related capital budgeting techniques with firm size. They were able to establish that small firms in Pakistan tended to use PB as their preferred method while large firms mainly used the single factor Capital Asset Pricing Model (CAPM) to ascertain the cost of capital. They also used CFOs and Chief Executive Officers (CEO) as respondents. In another study, Verma et al. (2009) identified the company's age and the CEO's educational background as the predicting factors for Indian respondents. In a more recent study, Gupta and Batra (2016) reported an association between the techniques used and firm size in India. In Kuwait, Al-Mutairi et al. (2018) found the nature of the project under assessment and the academic and professional capabilities of corporate personnel as the determinant for the choice of techniques. Within the context of developed countries, Daunfeldt \& Hartwig (2014) discovered that the choice of capital budgeting techniques of firms listed on the Stockholm Stock Exchange depended very much on leverage, growth opportunities, dividend payout ratios, choice of targeted debt ratio, industry and CEO personal traits. In Spain, de Andrés et al. (2015) sampled 140 non-financial firms. They revealed that corporate size and industry were factors that influenced the firms' preferred choice of capital budgeting techniques.

The review of these literature (Al-Muthairi et al., 2018; Gupta \& Batra, 2016; Daunfeldt \& Hartwig, 2014; Nishat \& Haq, 2009; Brounen et al., 2004) disclosed that various capital budgeting methods are adopted by various firms from various countries. In this regard, the 
capital budgeting techniques that were practised could be placed into three different categories, namely: naive, advanced and sophisticated. Naive practices include Discounted Payback (DPB), ARR and PB. Advanced techniques include sensivity analysis/break-even analysis, scenario analysis, IRR, modified IRR, NPV and profitability index. Finally, sophisticated techniques include Real Options, Game Theory Decisions, Decision Tree and CAPM. All these three categories of techniques have their own advantages and limitations. Their applications also depend on many factors (i.e. firms' age, CEOs' characteristics, and industry types). Over the years, scholars (Truong, Partington, \& Peat, 2008; Maroyi \& Poll, 2012; Lima, da Silveira, Matos, \& Xavier, 2017) also claimed that many firms across the globe are increasingly employing more sophisticated capital budgeting techniques for making investment decisions. This phenomenon is due to the expansion of increased uncertainty and risks. Since uncertainty affects future cash flows and causes estimation difficulties, various risk analysis and management science techniques have been developed to supplement the current traditional value-based decision models. In today's dynamic environment, firms need to be actively looking for opportunities so as to exploit their strategic capabilities. They need to seek improvement in every area of their business processes to ensure that they are quick to respond. The integration of sustainability in daily operations, for example, entails the right type of investment because an appropriate investment would help to maintain low prices and also achieve reduction in costs (Mangiaracina, Tumino, Miragliotta, Salvadori, \& Perego, 2017; Warren, 2014). Thus, it can be seen that decision-making for investments is not an easy task since it needs to be considered together with other risk factors such as technology upgrading, price fluctuations, competitors' actions, change in customer preferences, regulations, legislations, and also the political and economic environment. Therefore, it is essential that decision-makers employ an evaluation tool that has the advantage of integrating all the risk elements that are related to their investment decision making process.

\subsection{Prior Studies in Sri Lanka}

Considering the multiple and dynamic contexts discussed in the literature review, it is clear that decision-making for capital budgeting is still a complex persisting issue. A few studies (Nurullah \& Kengatharan, 2015; Koralalage \& Mudiyaselage, 2014) have examined capital budgeting 
practices in Sri Lanka. For instance, Koralalage and Mudiyaselage (2014) examined the use of capital budgeting techniques in 50 large businesses in Sri Lanka. They found that large firms relied heavily on NPV, IRR and DPB. In another study, Nurullah and Kengatharan (2015) focused on the capital budgeting practices of 32 listed manufacturing and trading companies in Sri Lanka. Their results disclosed that NPV, PB and IRR were the most predominant. Recently, Pathirawasam (2016) studied the capital budgeting practices of 44 Sri Lankan listed companies. It was revealed that NPV, IRR and PB were the most prevalent methods used.

Although these studies (Pathirawasam, 2016; Nurullah \& Kengatharan, 2015; Koralalage \& Mudiyaselage, 2014) focused on capital budgeting practices in Sri Lanka, their findings have been asymmetrical because they had focused on a particular sector only. In comparison, the current study aims to address the gap in literature by using a larger number of listed companies from multiple sectors listed on the Colombo Stock Exchange. It also aims to investigate how firm characteristics such as capital budgeting size, industry types, educational qualification of CFOs and CFOs tenure influence the companies' use of capital investment appraisal practices. The present study also advances the understanding of capital budgeting practices by comparing the current findings with those of previous studies conducted in different countries.

\subsection{Hypotheses Development}

As highlighted earlier, studies have documented that the decision on which capital budgeting methods to choose from, may be affected by "country effects" such as economic factors, cutting edge technology (i.e., decision support system), political factors, accounting policies, accounting standards and other infrastructure facilities. Therefore, even though capital budgeting theory is applicable to all countries, to a certain extent, the actual practices of capital budgeting vary (e.g., Graham \& Harvey, 2001, Hermes et al., 2007). Some scholars (Liu, Wu, Li, \& Li, 2015; Graham \& Sathye, 2018) have noted that since managers in the emerging country or developing economy would typically experience higher levels of environmental uncertainty, they were thus, more inclined towards using sophisticated capital budgeting practices. It was also highlighted that the use of sophisticated capital budgeting practices in Indonesia suited the country's context (Graham \& Sathye, 2018). For instance, formal approaches were found to be useful in mitigating risks throughout the project management. Thus, it is deduced that the same 
phenomenon is also likely to occur in Sri Lanka. This is because as an emerging economy, Sri Lanka has high levels of uncertainty due to local factors such as political instability as well as poor legal and regulatory frameworks (Appuhami \& Perera, 2016). Based on these arguments, it is hypothesised that:

$\mathrm{H}_{1}$ : Sri Lankan listed companies use sophisticated capital budgeting practices

The present study also considers the firms' underlying demographic characteristics which are expected to account for the differences in the firms' use of capital budgeting practices, vis-à-vis the size of the firm's capital budget, industry differences, and the CFO's educational qualification and experience in the field. All these factors are in line with prior studies (e.g. Verma et al., 2009; Bennouna, Meredith, \& Marchant, 2010; de Andrés et al., 2015).

Firm size is one of the major determinants in capital budgeting practices. Research (e.g., Ho \& Pike, 1992; Graham \& Harvey, 2001; Farragher, Kleiman, \& Sahu, 2001; Brounen et al., 2004; Verbeeten, 2006) has shown that large firms adopt more innovative capital budgeting methods such as sophisticated capital budgeting practices when compared to smaller firms (see Williams \& Seaman, 2001). Large firms, undoubtedly, have the capacity and resources to use sophisticated capital budgeting practices (Ho \& Pike, 1992). It was further documented by Payne, Heath and Gale (1999) as well as Ryan and Ryan (2002), that large firms' capital budget size tend to include more sophisticated capital budgeting practices because large firms have larger projects which makes using sophisticated capital budgeting practices less costly. Large firms were also more likely to have full time staff members for capital budgeting (Verbeeten, 2006) and they make considerable capital expenditures on new plants and equipment which require more sophisticated capital budgeting practices. However, the nature of the relationship between the size of a company's capital budget and its capital budgeting practice has not been clearly established in Sri Lanka. Thus, it is hypothesised that:

$\mathrm{H}_{2}$ : Sophisticated capital budgeting practices are used when a firm's capital budget is large.

Nonetheless, companies of different industrial types may vary in their use of capital budgeting practices. This may be attributed to the nature of the business activity, differences in technology, competition 
and human resource skills, the amount of investment in fixed assets, business risks, and so forth. Much empirical research in the past (e.g., Ho \& Pike, 1998) has shown that capital budgeting practices are different across industries. For example, the widespread use of real options and game theory is more prevalent in the pharmaceutical industry (e.g., Bowman \& Moskowitz, 2001; McGrath \& Nerkar, 2004), the extraction industry (e.g., Trigeorgis, 1993), the financial services industry and the high-tech industry (e.g., Billington, Johnson, \& Triantis, 2003; Verbeeten, 2006). Daunfeldt and Hartwig (2014) found that industry types influence the choice of capital budgeting practices. They also emphasised that manufacturing companies used more sophisticated methods because they were often larger and possessed more capital intensives with higher sunk costs. Based on this, it is hypothesised that:

$\mathrm{H}_{3}$ : Manufacturing firms in Sri Lanka use more sophisticated capital budgeting practices.

In one study, Hornstein (2013) found that managers and CFOs significantly influence corporate behaviour and performance. In particular, the educational qualifications of the CFOs served as a determinant of the capital budgeting practices (Graham \& Harvey, 2001). There has also been a general consensus that a $\mathrm{CFO}$ with a higher level of education will have fewer problems in understanding more sophisticated capital budgeting techniques, thus they will be capable of using them. A positive relationship has been identified between the educational background of CFOs and the use of sophisticated methods (Hermes et al., 2007; Daunfeldt \& Hartwig, 2014). Among the US sample, a positive association was found between the CFOs' education and the use of sophisticated capital budgeting practices (Graham \& Harvey, 2001). These findings were parallel to those observed in the Netherlands, Germany and France, but not in the UK (Brounen et al., 2004). In Scandinavia, Horn, Kjærland, Molnár and Steen (2015) stated that a quarter of the responding firms with CFOs who possess a PhD qualification use sophisticated capital budgeting practices. Thus, it is hypothesised that:

$\mathrm{H}_{4}$ : Chief Financial Officers (CFO) with higher educational qualifications use more sophisticated capital budgeting practices.

Besides their educational qualifications, the experiences of CFOs may also determine their choice of capital budgeting practices (Graham \& Harvey, 2001; Brounen et al., 2004). A handful of studies (e.g., Hermes 
et al., 2007; Verma et al., 2009) have reported that the experiences of CFOs will determine the use of capital budgeting methods since over time, they become more familiar with more sophisticated capital budgeting methods. Based on this, it is hypothesised that:

$\mathrm{H}_{5}$ : Chief Financial Officers with a greater number of years of experience use more sophisticated capital budgeting practices.

\section{Research Methodology}

This study employed a quantitative technique, using survey to collect data. The survey questions measuring the capital budgeting practices of the companies were adopted from previous seminal studies (Arnold \& Hatzopoulos, 2000; Graham \& Harvey, 2001; Brounen et al., 2004; Verma et al., 2009) (Appendix 1). Nonetheless, some fundamental changes were made to the questionnaire in order to adapt it to the Sri Lankan context. Respondents were asked to indicate on a five-point Likert scale (ranging from $1=$ never to $5=$ always) the extent to which they agreed with the statements provided. The questionnaire was pre-tested by an academic and industry expert. Feedback (e.g. inconsistency of wording, unclear or ambiguous items) from the pre-test was used to refine the questions for pilot testing and the larger study. In this study the pilot survey was conducted using a paper-based self-administered questionnaire with five CFOs. The respondents understood all of the questions in the way that the questionnaire was intended and they each spent 10 minutes completing the questionnaire. The CFOs did not express any concerns about the questionnaire, hence, the refined questionnaire was distributed among the larger group of potential respondents.

The larger study comprised a total of 287 companies which were listed on the Colombo Stock Exchange. They made up the total of Sri Lanka's small population of companies. By selecting the whole population, the results could be generalised. Each of the questionnaires was accompanied by a cover letter before they were mailed to the Chief Financial Officers (CFO) of the listed companies. The questionnaire survey was conducted between June to December 2013. Reminders were sent to CFOs to elicit a high response rate. In total, 186 questionnaires were retrieved, representing a response rate of 64 per cent. Table 1 depicts the sample characteristics of the respondents.

As depicted in Table 1, the recruited companies were mainly from the manufacturing industry (52.7 per cent) with a majority of the 
Table 1: Sample Characteristics of the Respondents

\begin{tabular}{|c|c|c|}
\hline Firm Characteristics & Frequency & Percentage \\
\hline \multicolumn{3}{|l|}{ Educational qualification of the CFO } \\
\hline Bachelor degree & 7 & 3.8 \\
\hline MBA & 54 & 29.0 \\
\hline Non-MBA Master's & 25 & 13.4 \\
\hline Above Master's degree & 97 & 52.2 \\
\hline Professional qualification & 3 & 1.6 \\
\hline \multicolumn{3}{|l|}{ Experience of the CFOs in Years } \\
\hline Less than 5 years & 7 & 3.8 \\
\hline $5-9$ years & 21 & 11.3 \\
\hline 10-19 years & 81 & 43.5 \\
\hline 20 years and more & 77 & 41.4 \\
\hline \multicolumn{3}{|l|}{ Types of Industry } \\
\hline Financial Service Industry & 9 & 4.8 \\
\hline Manufacturing Industry & 98 & 52.7 \\
\hline Diversified Holdings & 11 & 6.0 \\
\hline Health Care Industry & 6 & 3.2 \\
\hline Hotel Industry & 29 & 15.6 \\
\hline Other Non-financial Industry & 33 & 17.7 \\
\hline \multicolumn{3}{|l|}{ Size of the Capital Budget } \\
\hline Less than LKR 10 million & 17 & 9.2 \\
\hline LKR 10-99 million & 51 & 27.4 \\
\hline LKR 100-499 million & 3 & 39.2 \\
\hline LKR 500-999 million & 19 & 10.2 \\
\hline LKR 1 billion and over & 26 & 14.0 \\
\hline
\end{tabular}

companies headed by CFOs (94.6 per cent) who possessed Masters qualification and above. It is also interesting to note that more than half (52.2 per cent) of the CFOs also held a PhD degree. Most of the CFOs (86.7 per cent) also have academic qualifications in business related studies, with almost half (43.5 per cent) of them holding 10 to 19 years of work experience. In terms of the size of capital budget, a majority of the companies (39.2 per cent) have a capital budget of between LKR100-499 million. Only 14 per cent of the companies recorded a capital budget of above one billion. 


\section{Findings and Discussion}

\subsection{Prevalent Capital Budgeting Practices in Sri Lanka}

As discussed in the literature, there is a tendency among firms to use multi-methods in making capital budgeting decisions (e.g., Arnold \& Hatzopoulos, 2000). As a caveat, capital budgeting decision tools, namely capital budgeting methods and capital budgeting tools for incorporating risks, were subjected to principal component analysis with Varimax rotation, consistent with many research scholars (e.g., Verbeeten, 2006). The results are presented in Table 2.

Table 2: Principal Components Analysis with Varimax Rotation for Determining Capital Budgeting Methods

\begin{tabular}{lccc}
\hline & \multicolumn{3}{c}{ Components/Methods } \\
\cline { 2 - 4 } Variables & $\begin{array}{c}\text { Advanced } \\
\text { Capital } \\
\text { Budgeting } \\
\text { Practices }\end{array}$ & $\begin{array}{c}\text { Sophisticated } \\
\text { Capital } \\
\text { Budgeting } \\
\text { Practices }\end{array}$ & $\begin{array}{c}\text { Simple/Naive } \\
\text { Capital } \\
\text { Budgeting } \\
\text { Practices }\end{array}$ \\
\hline Probability Analysis & .819 & & \\
Scenario Analysis & .798 & & \\
Adjusting Required Return & .771 & & \\
Internal Rate of Return & .765 & & \\
Uncertainty Absorption in & .736 & & \\
$\quad$ Cash Flows & .697 & & \\
Sensitivity Analysis & .670 & & \\
Net Present Value & & .793 & .857 \\
Real Options & & .779 & .809 \\
Game Theory Decisions & & .750 & .667 \\
Decision Trees & & & \\
CAPM/ $\beta$ Analysis & & & \\
Discounted Payback Period & & & \\
Accounting Rate of Return & 5.822 & 2.108 & \\
Payback Period & $38.815 \%$ & $14.052 \%$ & \\
\hline Eigen Value & $38.815 \%$ & $52.867 \%$ & \\
Proportion of Variance Explained & & & \\
Cumulative Percentage Explained & & & \\
Cronbach's Alpha - Reliability of & 0.890 & & \\
$\quad$ factors & & & \\
\hline$\quad$ Kaiser-Meyer-Olkin Meas & & & \\
\hline
\end{tabular}

Kaiser-Meyer-Olkin Measure of Sampling Adequacy (.888); Bartlett's Test of Sphericity-Approx. Chi-Square (1221.845), $d f(105)$ 
In this regard, the findings were consistent with literature (e.g. Verbeeten, 2006; Wolffsen, 2012). The capital budgeting practices were grouped into three classes: advanced capital budgeting practices (probability analysis, IRR, scenario analysis, adjusting required return, uncertainty absorption in cash flows, sensitivity analysis and NPV); sophisticated capital budgeting practices (real options, CAPM/ $\beta$ analysis, game theory decisions and decision trees); and naive/simple capital budgeting practices (DPB, ARR and PB). Although techniques such as Adjusted Present Value, Profitability Index, and Value at Risk were included in the survey, they were found to be less popular among companies in Sri Lanka, therefore, they were eliminated in the factor analysis.

Table 3: Summary of the Prevalent Capital Budgeting Practices in Sri Lanka (\%)

\begin{tabular}{lcccccc}
\hline & Never & Rarely & $\begin{array}{c}\text { Some- } \\
\text { times }\end{array}$ & Often & $\begin{array}{c}\text { Always } \\
\text { Mean \& } \\
\text { Rank }\end{array}$ \\
\hline $\begin{array}{l}\text { Naive Method } \\
\text { DPBP }\end{array}$ & $1.1(2)$ & $10.8(20)$ & $64.0(119)$ & $24.2(45)$ & - & $3.11(9)$ \\
ARR & $3.8(7)$ & $13.4(25)$ & $61.8(115)$ & $19.9(37)$ & $1.1(2)$ & $3.01(10)$ \\
PBP & $2.2(4)$ & $13.4(25)$ & $34.4(64)$ & $37.6(70)$ & $12.4(23)$ & $3.45(8)$ \\
Advanced Method & & & & & & \\
Probability Analysis & $1.1(2)$ & $3.2(6)$ & $13.4(25)$ & $68.8(128)$ & $13.4(25)$ & $3.90(4)$ \\
Scenario Analysis & $1.6(3)$ & $5.4(10)$ & $12.4(23)$ & $65.1(121)$ & $15.6(29)$ & $3.88(5)$ \\
Adjusted RRR & $2.7(5)$ & $5.9(11)$ & $14.0(26)$ & $63.4(118)$ & $14.0(26)$ & $3.80(7)$ \\
IRR & $6.5(12)$ & $5.9(11)$ & $8.6(16)$ & $55.9(104)$ & $23.1(43)$ & $3.83(6)$ \\
Uncertainty absorption & $0.5(1)$ & $1.6(3)$ & $12.4(23)$ & $69.9(130)$ & $15.6(29)$ & $3.98(2)$ \\
$\quad$ in cash flows & & & & & & \\
Sensitivity Analysis & $1.6(3)$ & $8.1(15)$ & $11.3(21)$ & $52.7(98)$ & $26.3(49)$ & $3.94(3)$ \\
NPV & $1.6(3)$ & $2.2(4)$ & $12.4(23)$ & $51.6(96)$ & $32.3(60)$ & $4.11(1)$ \\
Sophisticated Method & & & & & & \\
Real Options & $78.0(145)$ & $15.6(29)$ & $6.5(12)$ & - & - & $1.28(13)$ \\
Game Theory Decisions & $83.9(156)$ & $26.0(14)$ & $2.2(4)$ & - & - & $1.18(14)$ \\
Decision Trees & $65.6(122)$ & $27.4(51)$ & $7.0(13)$ & - & - & $1.41(11)$ \\
CAPM/ $\beta$ Analysis & $77.4(144)$ & $11.8(22)$ & $8.6(16)$ & $2.2(4)$ & - & $1.35(12)$ \\
\hline
\end{tabular}

Note $:$ DPBP $=$ Discounted Payback Period, PBP $=$ Payback Period, ARR $=$ Accounting Rate of Return, RRR = Required Rate of Return, IRR = Internal Rate of Return, NPV = Net Present Value. Number of respondents in parentheses. 
As can be noted from the results, the NPV was the most preferred method of capital budgeting, with a mean value of 4.11 . This was followed by Uncertainty absorption in cash flows $(M=3.98)$, Sensitivity analysis $(M=3.94)$, Probability analysis $(M=3.90)$, Scenario analysis $(\mathrm{M}=3.88)$, IRR $(\mathrm{M}=3.83)$, Adjusting RRR $(\mathrm{M}=3.80), \mathrm{PBP}(\mathrm{M}=3.45)$, $\operatorname{DBP}(\mathrm{M}=3.11)$ and ARR $(\mathrm{M}=3.01)$. Methods such as Real option, Game theory decisions, Decision tree and CAPM/ $\beta$ analysis which had been classified as sophisticated methods were, however, not popular, yielding mean values of less than 2.0. Based on the mean value and percentage analysis, it is fair to say that the more dominant capital budgeting practice used by Sri Lankan companies is the advanced capital budgeting practices (top seven practices). Further analysis (chi-square test) was conducted to test the hypothesis and the results are presented in Tables 4 and 5.

Table 4: Chi-Square test of Naive, Advanced and Sophisticated Methods

\begin{tabular}{lrcr}
\hline & Naive & Advanced & Sophisticated \\
\hline Observed (O) & 85.13 & 93.17 & 6.62 \\
Expected (E) & 61.64 & 61.64 & 61.64 \\
O-E & 23.49 & 31.53 & -55.02 \\
$(\mathrm{O}-\mathrm{E})^{2}$ & 551.78 & 994.14 & 3027.20 \\
$(\mathrm{O}-\mathrm{E})^{2} / \mathrm{E}$ & 8.95 & 16.13 & 49.11 \\
\hline \multicolumn{4}{c}{ Calculated chi-square $\Sigma(\mathrm{O}-\mathrm{E})^{2} / \mathrm{E}=74.19$} \\
\multicolumn{3}{c}{$(d f=2)$} \\
\hline
\end{tabular}

The observed values were the average percentage of "sometimes", "often" and "always". As a caveat, it was assumed that the three capital budgeting practices were equally used by the companies, thus the expected value was the average value of three types of capital budgeting practices $[(85.13+93.17+6.62) / 3]$. As can be seen in Table 4 , the calculated chi-square is 74.19 , which is greater than the chi-square critical value of 0.05 (5.99) and 0.01 (9.21). Thus, there is sufficient evidence to verify that capital budgeting practices are different at the 0.01 significance level. The high percentage of the advanced capital budgeting practices indicate that they were practices that were more prevalent among companies in Sri Lanka. However, it was noted that the percentages between naive capital budgeting practices and advanced capital budgeting practices 
were close. This makes it difficult to ascertain what the true difference between those two methods were. Therefore, the chi-square test was further performed to examine the significant differences between the naive and advanced methods ["often" and "always" was considered in comparison to Verma et al. (2009)].

Table 5: Chi-Square test of Naive and Advanced Methods

\begin{tabular}{lrr}
\hline & Naive & Advanced \\
\hline Observed (O) & 31.7 & 81.1 \\
Expected (E) & 56.415 & 56.415 \\
O-E & -24.685 & 24.685 \\
$\left(\mathrm{O}-\mathrm{E}^{2}\right.$ & 609.35 & 609.35 \\
$(\mathrm{O}-\mathrm{E})^{2} / \mathrm{E}$ & 10.80 & 10.80 \\
\hline
\end{tabular}

Calculated chi-square $\Sigma(\mathrm{O}-\mathrm{E})^{2} / \mathrm{E}=21.60$

$(d f=1)$

As can be seen in Table 5, the calculated chi-square was 21.60, which is greater than the chi-square critical value of 0.05 (3.84) and 0.01 (6.63). Thus, there is sufficient evidence to indicate that capital budgeting practices were different at the 0.01 significance level between the naive and advanced methods. Consequently, there is also sufficient statistical evidence to infer that the advanced capital budgeting practices were more prevalent in Sri Lankan firms. In this regard, $\mathrm{H}_{1}$ stating that Sri Lankan listed companies use sophisticated capital budgeting practices is not supported.

From the results indicated in Table 6, it can be noted that the most preferred capital budgeting technique used by companies in Sri Lanka is NPV (always/often 83.9 per cent), followed by IRR (always/often 79 per cent), PB (always/often 50 per cent), ARR (always/often 21 per cent) and DPB (always/often 24.2 per cent). In contrast, Graham and Harvey (2001) noted that the most preferred technique used in the US was IRR (always/almost always 75.7 per cent), followed by NPV (always/almost always 74.9 per cent), and PB (always/almost always 56.7 per cent).

From the European perspective, Brounen et al. (2004) found that PB was the most frequently used capital budgeting method in the UK (69.2 per cent), the Netherlands (64.7 per cent), Germany (50 per cent) and France (50.9 per cent). The IRR and NPV methods were also 
Table 6: Comparison of the Current Results with Previous Studies Using Similar Questionnaires on Capital Investment Appraisal Practices/Capital Budgeting Practices

\begin{tabular}{|c|c|c|c|c|c|c|c|}
\hline & Current & Verma & Graham \& & \multicolumn{4}{|c|}{ Brounen et al. (2004) } \\
\hline Country & Sri Lanka & India & USA & UK & $\begin{array}{l}\text { Nether- } \\
\text { land }\end{array}$ & $\begin{array}{l}\text { Ger- } \\
\text { many }\end{array}$ & France \\
\hline Year Surveyed & 2013 & 2009 & 1999 & \multicolumn{4}{|c|}{$2002 / 2003$} \\
\hline Survey Sample & 287 & 100 & 4440 & 2000 & 500 & 2000 & 2000 \\
\hline Usable Response & 186 & 30 & 392 & 68 & 52 & 132 & 61 \\
\hline \multirow[t]{3}{*}{$\begin{array}{l}\text { Percentage of } \\
\text { Response Rate }\end{array}$} & 64 & 30 & 9 & \multicolumn{4}{|c|}{5} \\
\hline & \multicolumn{7}{|c|}{ Capital Budgeting Techniques (Percentage of Usage) } \\
\hline & \multicolumn{2}{|c|}{ Always/or often } & \multicolumn{5}{|c|}{ Always/or almost always } \\
\hline PB & 50.0 & 80.0 & 56.7 & 69.2 & 64.7 & 50.0 & 50.9 \\
\hline DPB & 24.2 & 23.3 & 29.5 & 25.40 & 25.0 & 30.5 & 11.3 \\
\hline ARR & 21.0 & 26.7 & 20.0 & 38.10 & 25.0 & 32.2 & 16.1 \\
\hline NPV & 83.9 & 63.3 & 74.9 & 47.0 & 70.0 & 47.6 & 35.1 \\
\hline IRR & 79.0 & 76.7 & 75.7 & 53.1 & 56.0 & 42.2 & 44.1 \\
\hline $\begin{array}{l}\text { Adjusted } \\
\text { Present Value }\end{array}$ & - & 16.6 & 11.0 & 14.1 & 8.16 & 7.8 & 14.6 \\
\hline $\begin{array}{l}\text { Profitability } \\
\text { Index }\end{array}$ & - & 40.0 & 12.0 & 15.9 & 8.16 & 16.1 & 37.7 \\
\hline
\end{tabular}

Capital Budgeting Method of Incorporating Risk (Percentage of Usage)

\begin{tabular}{|c|c|c|c|c|c|c|c|}
\hline \multirow[b]{2}{*}{$\begin{array}{r}\text { Sensitivity } \\
\text { Analysis }\end{array}$} & \multicolumn{2}{|c|}{ Always/or often } & \multicolumn{5}{|c|}{ Always/or almost always } \\
\hline & 79.0 & 73.4 & 51.5 & 42.9 & 36.7 & 28.1 & 10.4 \\
\hline $\begin{array}{l}\text { Value at risk/ } \\
\text { other simulation } \\
\text { analysis }\end{array}$ & - & 20.0 & 13.7 & 14.5 & 4.3 & 23.7 & 29.8 \\
\hline CAPM & 2.2 & 36.7 & - & - & - & - & - \\
\hline High cut off rates & - & 16.7 & 56.9 & 27.0 & 41.7 & 28.8 & 3.85 \\
\hline Shorter pay-back & & 50.0 & - & - & - & - & - \\
\hline Real Option & $\begin{array}{c}6.5 \\
\text { (some- } \\
\text { times) }\end{array}$ & 10.0 & 26.6 & 29.0 & 34.7 & 44.0 & 53.1 \\
\hline
\end{tabular}

Note: DPBP $=$ Discounted Payback Period, PBP $=$ Payback Period, ARR $=$ Accounting Rate of Return, RRR $=$ Required Rate of Return, IRR = Internal Rate of Return, NPV $=$ Net Present Value. 
commonly applied in the UK, the Netherlands, Germany and France. Among firms in India, Verma et al. (2009) found that the most preferred technique was PB (always/often 80 per cent), followed by IRR (always/ often 76.7 per cent) and NPV (always/often 63.3 per cent). In the current study, only 6.5 per cent of the CFOs in Sri Lanka reported using Real Options "sometimes" $(\mathrm{M}=1.28)$ for evaluating their investment projects. Therefore, it is fair to say that Real Options was more preferred by Sri Lankan firms (6.5 per cent) only at the embryonic stage, unlike France (53.6 per cent), Germany (44.0 per cent), the Netherlands (34.7 per cent), the UK (29.0 per cent), and the US (26.6 per cent). In comparison to India, the results drawn from Sri Lanka (10 per cent) were somewhat similar to those of India which used Real Options (Verma et al., 2009). From these reports, it can be said that different practices are applied by different countries, hence it can be deduced that the "country effects" have an influence on the practices. Country effects such as economic policies, taxation systems, accounting policies and social practices, culture of the people, technological factors, government control, political factors and infrastructure facilities may differ from one country to another, from one company to another company and from one project to another project. In addition to this, it may be apt to add that while technology has boosted academic research and the appearance of a more complex model, firms in Sri Lanka may not always be able to keep up with the trend due to national constraints such as very less usage of human capital which leads to high cost for investment appraisal process and lack of effective corporate governance mechanism when compared with well developed countries.

\subsection{Firms' Characteristics and Capital Budgeting Practices}

The current survey has carefully considered firms' underlying characteristics such as: size of capital budget, educational qualification of CFOs, experience of CFOs and types of industry. The aim is to uncover how these characteristics affect differences in the use of capital budgeting practices. Each characteristic (i.e. educational qualifications of CFO, experiences of CFO, types of industry and size of capital budget) is grouped into two different categories, following the recommendations of Graham and Harvey (2001) and Brounen et al. (2004). The educational qualifications of the CFOs are grouped into MBA level and above and non-MBA and others. The experience of the CFOs are grouped as short tenure (less than 10 year) and long tenure (10 years 
and above). The types of industry are grouped into manufacturing and non-manufacturing while the size of capital budget is grouped as large (capital budget greater than LKR 1 billion) and small (capital budget less than 1 LKR billion). The mean difference in the statistics of the independent sample t-test is employed. The differences in the use of the capital budgeting practices in terms of firm characteristics are summarised in Table 7.

Based on Table 7, it is observed that the use of payback criterion is significant at 0.05 ; it is mostly preferred by small firms mainly managed by CFOs with non-MBA educational qualifications and with a short tenure in experience. Industry differences do not have any significant impact in the use of PB but DPB is more significantly used by small firms managed by CFOs with non-MBA educational qualifications. ARR is also used by small firms more than by large firms. However, the difference is not statistically significant. ARR is primarily applied by non-MBA CFOs and it is preferred by non-manufacturing firms. In contrast, NPV and IRR are used more by large firms which are significantly managed by MBA-qualified CFOs with long tenures. These differences are statistically significant at 0.01 . Similarly, sophisticated capital budgeting practices, in terms of Real Option and Game Theory Decisions, are significantly preferred by large companies managed by MBA-qualified CFOs who have long tenures rather than by small companies. Findings of the current study is consistent with the findings of prior studies noted by Graham and Harvey (2001), Brounen et al. (2004) and Verma et al. (2009) who had mentioned that large firms were most likely to use more sophisticated capital budgeting techniques when it comes to evaluating large and risky capital projects. According to the study of Brounen et al. (2004), PB was a more popular method used by small firms except for the UK companies. Simultaneously, NPV was used most significantly by large firms managed by CFOs with MBA qualifications in the Netherlands, Germany and France. A similar pattern is also observed in Sri Lanka where it is noted that small firms in Sri Lanka are less likely to use both NPV and sensitivity analysis. The findings of this study are also in concordance with Graham and Harvey (2001).

When considering the firms' underlying characteristics which may influence firms' usage of risk-taking tools in capital budgeting practice, it appears that sensitivity analysis, uncertainty absorption in cash flows and adjusting the required return, are significantly preferred by large firms more than by small firms. Moreover, these are also significantly managed by MBA-qualified CFOs rather than non-MBA CFOs. The 
Lingesiya Kengatharan and Mohamed Nurullah

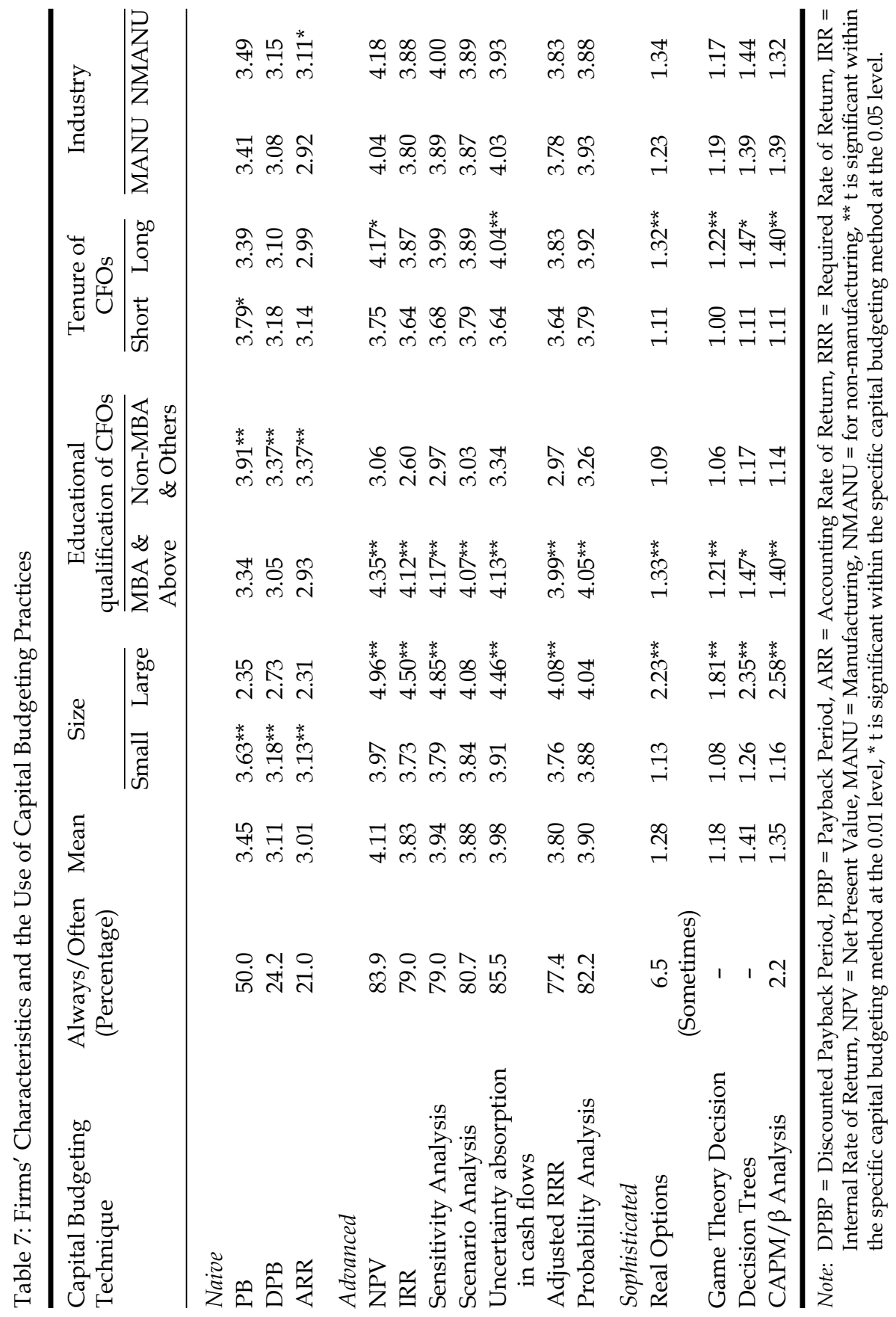


scenario and probability analysis are also significantly managed by MBA qualified CFOs rather than non-MBA qualified CFOs. Further to that, the usage of decision trees and CAPM/ $\beta$ analysis is significantly most frequently cited by large firms rather than by small firms. Likewise, these are significantly managed by MBA-qualified CFOs who have a significantly longer tenure with the firms.

While naive capital (simple) budgeting practices are significantly used by small firms, advanced and sophisticated capital budgeting practices are significantly used by large firms. Consequently, Hypothesis 2 which states that sophisticated capital budgeting practices are used when a firm's capital budget is large, is supported. In all cases except ARR, the type of industry is not significantly different on the use of capital budgeting practices. The results only supported the notion that the use of ARR is significantly greater in non-manufacturing firms than in manufacturing firms. Therefore, in the majority of cases which hypothesised $\left(\mathrm{H}_{3}\right)$ that manufacturing firms use more sophisticated capital budgeting practices, the hypothesis is not supported. Naive (simple) capital budgeting practices are significantly used by CFOs with non-MBA qualification while advanced and sophisticated capital budgeting practices are significantly used by CFOs with MBA qualifications. Accordingly, Hypothesis 4 which states that CFOs with higher educational qualifications use more sophisticated capital budgeting practices is supported. In all cases, simple (naive) capital budgeting practices are mostly used by CFOs with short tenure (significantly different only for PB) but advanced and sophisticated capital budgeting practices (NPV, real option, game theory decision, uncertainty absorption in cash flows, decision trees and CAPM/ $\beta$ analysis) are significantly used by CFOs with long tenures. Subsequently, Hypothesis 5 which states that CFOs with a greater number of years of experience use more sophisticated capital budgeting practices, is supported.

\section{Conclusion and Implications}

Capital budgeting is of paramount importance to firms when making corporate financial decisions. This is because it facilitates firms in making the right investment decisions that will ensure corporate profitability and growth. In this study, an attempt was made to empirically investigate the capital budgeting practices in an emerging economy, specifically Sri Lanka. A questionnaire was distributed to a sample of 287 companies listed in the Colombo Stock Exchange. The results 
of the analysis highlighted that companies in Sri Lanka tend to choose advanced rather than sophisticated capital budgeting techniques. While some scholars (Liu et al., 2015; Graham \& Sathye, 2018) assert that managers in emerging countries have started to use sophisticated capital budgeting practices since they were more exposed to higher levels of environmental uncertainty, this phenomenon was found to be different in Sri Lanka. A comparison of the findings of this study was also made with previous studies conducted in developed countries such as the UK, the Netherlands, Germany and France (Graham \& Harvey, 2001; Brounen et al., 2004). The comparison showed that developed economies used sophisticated techniques more frequently while real options were rarely used by companies in Sri Lanka. Although there is a widespread use of sophisticated capital budgeting practices (Maroyi \& Poll, 2012; Baker, Dutta, \& Saadi, 2011) within emerging economies since they are facing higher uncertain environment, this situation was not observed in Sri Lanka. Our current findings show that despite the fact that real options had been introduced more than 30 years ago, companies were still using less complex and traditional methods. Nevertheless, the choice to use more sophisticated techniques vs. naive (simple) alternatives tend to vary with firms' attributes (size, available human capital, etc.).

This study has revealed that capital budgeting practices were influenced by the background of the CFOs, in terms of their education as well as experiences. This outcome was expected because the decision is unstructured and involves high risks. Hence, in many cases, the CFOs tend to use various methods based on their level of education and experiences. CFOs with MBA or PhD degrees were expected to utilise their knowledge, skills and expertise to enable themselves to use more sophisticated techniques. This finding suggests that the factors affecting capital budgeting practices are reflected through the CFOs' education, background and perspective. Notwithstanding this, as the application of sophisticated budgeting is more complex and entails a substantial cost, time and effort, it is expected that large firms would be more inclined towards using sophisticated budgeting practices rather than their small counterparts. This result implies that small firms in Sri Lanka were less ready to use sophisticated capital budgeting techniques due to less access to human capital, which causes sophisticated methods to be more difficult. This research has provided valuable insights into the capital budgeting practices that are practised in the Sri Lankan context. Considering the importance of sophisticated capital budgeting in mitigating risks, especially for emerging countries 
such as Sri Lanka, it is suggested that firms in the country start thinking about the appropriate level of sophisticated capital budgeting to be used for firms' net benefits against costs. It is also recommended that the key to improve the capital budgeting processes would be by ensuring that proper training is conducted for the decision makers in the company, especially the small firms.

\section{Limitations and Future Direction}

Many studies conducted in developed countries (Graham \& Harvey, 2001; Brounen et al., 2004) have found that firms used more sophisticated capital budgeting practices. Nonetheless, in Sri Lanka, advanced capital budgeting practices were more prevalent. Therefore, future research needs to consider the challenges faced by CFOs with regards to the use of sophisticated capital budgeting practices (i.e. organisational barriers/knowledge gap of CFOs, technological challenges) as these can lead to increased performance.

Future research may also consider investigating other organisational characteristics (e.g. business unit strategies, reward and incentive structures, distribution of decision rights and financial structure) which have been shown to affect capital budgeting practices. As this study focused on capital budgeting practices and the influence of firms' characteristic on the choice, future researchers could focus on the behavioural aspects.

No study has attempted to identify the relationship between supportive capital information systems (software products that make the required analysis easier in comparison with manual systems) and capital budgeting decision-making. Similarly, the environment in which organisations work, can impact on their ability to make quality decisions. Based on this, future researchers should concentrate on scanning organisational environments which can contribute to making good investment decisions rather than depending purely on financial theories. This is of paramount importance in the current context.

\section{References}

Al-Mutairi, A., Naser, K., \& Saeid, M. (2018). Capital budgeting practices by non-financial companies listed on Kuwait Stock Exchange (KSE). Cogent Economics \& Finance, 6(1), 1-18. http://dx.doi.org/10.1080/23322039.2018. 1468232 
Appuhami, R., \& Perera, S. (2016). Management controls for minimising risk in public-private partnerships in a developing country: Evidence from Sri Lanka. Journal of Accounting \& Organizational Change, 12(3), 408-431. http:/ / dx.doi.org/10.1108/JAOC-10-2013-0075

Arnold, G.C., \& Hatzopoulos, P.D. (2000). The theory-practice gap in capital budgeting: Evidence from the United Kingdom. Journal of Business Finance $\mathcal{E}$ Accounting, 27(5-6), 603-626. http:/ / dx.doi.org/10.1111/1468-5957.00327

Babu, C.P., \& Sharma, A. (1995). Capital budgeting practices in Indian industry: An empirical study. ASCI Journal of Management, 25(1), 34-43.

Baker, H.K., Dutta, S., \& Saadi, S. (2011). Management views on real options in capital budgeting. Journal of Applied Finance, 21(1), 18-29.

Bennouna, K., Meredith, G.G., \& Marchant, T. (2010). Improved capital budgeting decision making: Evidence from Canada. Management Decision, 48(2), 225-247. http:/ / dx.doi.org/10.1108/00251741011022590

Billington, C., Johnson, B., \& Triantis, A. (2003). A real options perspective on supply chain management in high technology. Journal of Applied Corporate Finance, 15(2), 32-43. http:/ / dx.doi.org/ 10.1111/j.1745-6622.2002.tb00693.x Bowman, E.H., \& Moskowitz, G.T. (2001). Real options analysis and strategic decision making. Organizations Science, 12(6), 772-777. http://dx.doi.org/ 10.1287/orsc.12.6.772.10080

Brounen, D., de Jong, A., \& Koedijk, K. (2004). Corporate finance in Europe: Confronting theory with practice. Financial Management, 33(4), 71-101.

Central Bank of Sri Lanka. (2017). Annual Report, Colombo, Sri Lanka: Author. Retrieved from http://www.cbsl.lk

Daunfeldt, S-O., \& Hartwig, F. (2014). What determines the use of capital budgeting methods? Evidence from Swedish listed companies. Journal of Finance and Economics, 2(4), 101-112. http:/ / dx.doi.org/10.12691/jfe-2-4-1

de Andrés, P., de Fuente, G., \& San Martín, P. (2015). Capital budgeting practices in Spain. BRQ Business Research Quarterly, 18(1), 37-56. http://dx.doi.org/ 10.1016/j.brq.2014.08.002

Dixit, A.K., \& Pindyck, R.S. (1994). Investment under uncertainty. Princeton, New Jersey: Princeton University Press.

Farragher, E.J., Kleiman, R.T., \& Sahu, A.P. (2001). The association between the use of sophisticated capital budgeting practices and corporate performance. The Engineering Economist, 46(4), 300-311. http://dx.doi.org/ 10.1080/00137910108967579

Graham, J.R., \& Harvey, C.R. (2001). The theory and practice of corporate finance: Evidence from the field. Journal of Financial Economics, 60(2-3), 187243. http:/ / dx.doi.org/ 10.1016/S0304-405X(01)00044-7

Graham, P., \& Sathye, S. (2018). National differences in capital budgeting systems: A comparison between Indonesian and Australian firms. Asian Journal of Business and Accounting, 11(1), 37-70.

Greenberg, D. (2013). Sri Lanka: An emerging economy that is increasingly attractive to foreign investors. Retrieved from https://bigemerging 
economies.wordpress.com/2011/07/13/sri-lanka-an-emerging-economy that-is-increasingly-attractive-to-foreign-investors/

Gupta, V.K., \& Batra, S. (2016). Entrepreneurial orientation and firm performance in Indian SMEs: Universal and contingency perspectives. International Small Business Journal, 34(5), 660-682. http://dx.doi.org/ 10.1177/0266242615577708

Hermes, N., Smid, P., \& Yao, L. (2007). Capital budgeting practices: A comparative study of the Netherlands and China. International Business Review, 16(5), 630-654. http:/ / dx.doi.org/10.1016/j.ibusrev.2007.05.002

Ho, S.S.M., \& Pike, R.H. (1992). Adoption of probabilistic risk analysis in capital Budgeting and corporate Investment. Journal of Business Finance and Accounting, 19(3), 387-405. http://dx.doi.org/10.1111/j.1468-5957.1992. tb00631.x

Ho, S.S.M., \& Pike, R.H. (1998). Organizational characteristics influencing the use of risk analysis in strategic capital investment. The Engineering Economist, 43(3), 247-268. http:/ / dx.doi.org/10.1080/00137919808903198

Horn, A., Kjærland, F., Molnár, P., \& Steen, B.W. (2015). The use of real option theory in Scandinavia's largest companies. International Review of Financial Analysis, 41(October), 74-81. http://dx.doi.org/10.1016/j.irfa.2015.05.026

Hornstein, A.S. (2013). Corporate capital budgeting and CEO turnover. Journal of Corporate Finance, 20(April), 41-58. http://dx.doi.org/10.1016/j.jcorpfin. 2012.11.003

International Federations of Accountants. (2013). Handbook of international quality control, auditing, reviews, other assurance and related services pronouncements. New York, NY: Author. Retrieved from www.ifac.org

Keršytė, A. (2011). Capital budgeting process: Theoretical aspects. Journal of Economics \& Management, 16(1), 1130-1134.

Koralalage, W.B.Y., \& Mudiyaselage, C.L.K.R.R. (2014). The use of capital budgeting techniques in large businesses: Evidence from Sri Lanka. International Journal of Arts \& Commerce, 3(9), 77-84.

Lima, A.C., da Silveira, J.A.G., Matos, F.R.N., \& Xavier, A.M. (2017). A qualitative analysis of capital budgeting in cotton ginning plants. Qualitative Research in Accounting \& Management, 14(3), 210-229. http://dx.doi.org/ 10.1108/QRAM-07-2016-0055

Lintner, J. (1965). The valuation of risky assets and the selection of risky investments in stock portfolios and capital budgets. Review of Economics and Statistics, 47(1), 13-37. http:/ /dx.doi.org/10.2307/1924119

Liu, L., Wu, J., Li, P., \& Li, Q. (2015). A social-media-based approach to predicting stock comovement. Expert Systems with Applications, 42(8), 3893-3901. http:/ / dx.doi.org/10.1016/j.eswa.2014.12.049

Mangiaracina, R., Tumino, A., Miragliotta, G., Salvadori, G., \& Perego, A. (2017, September). Smart parking management in a smart city: Costs and benefits. Paper presented at the 2017 IEEE International Conference on Service 
Operations and Logistics, and Informatics, Bari, Italy. http://dx.doi.org/ 10.1109/SOLI.2017.8120964

Mao, J.C.T. (1970). Survey of capital budgeting: Theory and practice. Journal of Finance, 25(2), 349-360. http://dx.doi.org/10.1111/j.1540-6261.1970. tb00513.x

Maroyi, V., \& van der Poll, H.M. (2012). A survey of capital budgeting techniques used by listed mining companies in South Africa. African Journal of Business Management, 6(32), 9279-9292.

McGrath, R.G., \& Nerkar, A. (2004). Real options reasoning and a new look at the R and D investment strategies of pharmaceutical firms. Strategic Management Journal, 25(1), 1-21. http://dx.doi.org/10.1002/smj.358

Meyer, K.S., \& Kiymaz, H. (2015). Sustainability considerations in capital budgeting decisions: A survey of financial executives. Accounting and Finance Research, 4(2), 1-13. http://dx.doi.org/10.5430/afr.v4n2p1

Mutairi, M.A., Tian, G., Hasan, H., \& Tan, A. (2012). Corporate governance and corporate finance practices in a Kuwait Stock Exchange market listed firm: A survey to confront theory with practice. Corporate Governance: The International Journal of Business in Society, 12(5), 595-615. http://dx.doi. org/10.1108/14720701211275523

Nishat, M., \& Haq, Z. (2009, April). Capital budgeting practices: A survey of Pakistani firms. Paper presented at the South Asian Management Forum (SANF 10), Bhutan.

Nurullah, M., \& Kengatharan, L. (2015). Capital budgeting practices: Evidence from Sri Lanka. Journal of Advances in Management Research, 12(1), 55-82. http://dx.doi.org/10.1108/JAMR-01-2014-0004

Pathirawasam, C. (2016). Capital budgeting practices: Evidence from Sri Lanka listed companies. International Journal of Management and Applied Science, 2(5), 23-26.

Payne, J.D., Heath, W.C., \& Gale, L.R. (1999). Comparative financial practice in the US and Canada: Capital budgeting and risk assessment techniques. Financial Practice and Education, 9(1), 16-24.

Roll, R. (1977). A critique of the asset pricing theory's tests' part I: On past and potential testability of the theory. Journal of Financial Economics, 4(2), 129176. http://dx.doi.org/10.1016/0304-405X(77)90009-5

Ryan, P.A., \& Ryan, G.P. (2002). Capital budgeting practices of the Fortune 1000: How have things changed? Journal of Business and Management, 8(4), 355-364.

Sangster, A. (1993). Capital investment appraisal techniques: A survey of current usage. Journal of Business Finance \& Accounting, 20(3), 307-332. http:// dx.doi.org/10.1111/j.1468-5957.1993.tb00258.x

Segelod, E. (1998). Capital budgeting in a fast-changing world. Long Range Planning, 31(4), 529-541. http://dx.doi.org/10.1016/S0024-6301(98)80046-0

Sharpe, W.F. (1964). Capital asset prices: A theory of market equilibrium under conditions of risk. Journal of Finance, 19(3), 425-442. http://dx.doi.org/ 10.1111/j.1540-6261.1964.tb02865.x 
Singh, S., Jain, P.K., \& Yadav, S.S. (2012). Capital budgeting decisions: Evidence from India. Journal of Advances in Management Research, 9(1), 96-112. http:/ / dx.doi.org/10.1108/09727981211225671

Slagmulder, R., Bruggeman, W., \& Wassenhove, L. (1995). An empirical study of capital budgeting practices for strategic investments in CIM technologies. International Journal of Production Economics, 40(2-3), 121-152. http://dx.doi. org/10.1016/0925-5273(95)00069-7

Trigeorgis, L. (1993). Real options and interactions with financial flexibility. Financial Management, 22(3), 202-224.

Truong, G., Partington, G., \& Peat, M. (2008). Cost-of-capital estimation and capital-budgeting practice in Australia. Australian Journal of Management, 33(1), 95-121. http://dx.doi.org/10.1177/031289620803300106

Verbeeten, F.H.M. (2006). Do organizations adopt sophisticated capital budgeting practices to deal with uncertainty in the investment decision? A research note. Management Accounting Research, 17(1), 106-120. http:// dx.doi.org/10.1016/j.mar.2005.07.002

Verma, S., Gupta, S., \& Batra, R. (2009). A survey of capital budgeting practices in corporate India. Vision: The Journal of Business Perspective, 13(3), 1-17. http://dx.doi.org/10.1177/097226290901300301

Warren, L. (2014). Management control, regulation and investment uncertainty in the UK electricity generation market. In D. Otley \& K. Soin (Eds.), Management control and uncertainty (pp. 193-206). London: Palgrave Macmillan.

Williams, J.J., \& Seaman, A.E. (2001). Predicting change in management accounting systems: National culture and industry effects. Accounting, Organizations and Society, 26(4-5), 443-460. http://dx.doi.org/10.1016/ S0361-3682(01)00002-2

Wolffsen, P. (2012). Modification of capital budgeting under uncertainty. Taikomoji ekonomika: sisteminiai tyrimai, 6(2), 143-159.

World Bank Group (2018). The world bank in Sri Lanka. Retrieved from https:// www.worldbank.org/en/country/srilanka/overview

Zubairi, H.J., \& Amin, F. (2008). Capital budgeting - decision making practices in Pakistan (Working Paper). Karachi, Pakistan: Institute of Business Management. http://dx.doi.org/10.2139/ssrn.1308662 


\section{Appendix 1}

\section{ASSESSING COMPANY'S DEMOGRAPHIC INFORMATION AND CORPORATE PRACTICES REGARDING CAPITAL BUDGETING}

\section{Section 1}

I) Please answer to the following questions for general information of your company

a. Name and age of your company:

b. Ownership of company: Public or Private

c. What is your company's planning horizon for capital expenditure budgets: (choose best option)

1 year ahead $\square \quad 2$ years ahead $\square \quad 3$ years ahead $\square \quad 4$ years ahead $\square \quad$ More than 4 years ahead $\square$

d. Size of capital budget in LKR:

$<10$ Million $\square$ 10-99 Million $\square$ 100-499 Million $\square$ 500-999 Million $\square$

$>1$ Billion $\square$

II) Please answer to the following questions for general information of respondents

e. Please specify length of your experience in capital budgeting practices (in years):

f. Your educational qualifications:

Undergraduate $\square \quad$ Bachelor degree $\square \quad$ MBA $\square \quad$ Non-MBA $\square \quad$ Masters $\square$ PhD $\square$ Professional $\square$ Any other

\section{Section 2}

Specify the purpose of your company's capital budgeting (check all that apply)

Expansion into new business

Investing new facilities

New product development

Expansion of existing business

Diversification

Mergers and acquisition

$\begin{array}{lll}\square & \text { Equipment replacement } & \square \\ \square & \text { Modernisation } & \square \\ \square & \text { Employing new technology } & \square \\ \square & \text { Research and development } & \square \\ \square & \text { Training and development } & \square \\ \square & \text { Any other capital projects } & \square\end{array}$

\section{Section 3}

From the following list of common capital budgeting methods (investment appraisal techniques), please tick one box for each question to indicate primary and secondary capital budgeting techniques. If you have extra comments, please leave them to the end of the questionnaire.

\begin{tabular}{lcclccc}
\hline $\begin{array}{l}\text { Capital budgeting } \\
\text { methods }\end{array}$ & $\begin{array}{l}\text { Pri- } \\
\text { mary }\end{array}$ & $\begin{array}{c}\text { Second- Neither } \\
\text { ary }\end{array}$ & $\begin{array}{l}\text { Capital budgeting } \\
\text { methods }\end{array}$ & \multicolumn{2}{c}{$\begin{array}{l}\text { Pri- Second- Neither } \\
\text { mary }\end{array}$} \\
\hline $\begin{array}{l}\text { Simple payback } \\
\text { period (PB) }\end{array}$ & $\square$ & $\square$ & $\square$ & $\begin{array}{l}\text { Adjusted present } \\
\text { value (APV) }\end{array}$ & $\square$ & $\square$ \\
\hline
\end{tabular}


Discounted payback period (DPB)

Accounting rate of return (ARR)

Net present value (NPV)

Internal rate of return (IRR)

Modified internal rate of return

(MIRR)
Profitability

Index (PI)

Real option

theory

Game theory

decision

Non financial decision rules (please specify):

Please state if you use any other methods

Please assign the capital budgeting techniques/methods presented below a number between $(1=$ never, 2 = rarely, $3=$ sometimes, $4=$ often, 5 = always $)$ depending on the degree of usage of capital budgeting tools for a particular investment.

\begin{tabular}{|c|c|c|c|c|c|c|c|c|c|c|c|}
\hline $\begin{array}{l}\text { Capital budgeting } \\
\text { methods }\end{array}$ & 1 & 2 & 3 & 4 & 5 & $\begin{array}{l}\text { Capital budgeting } \\
\text { methods }\end{array}$ & 1 & 2 & 3 & 4 & 5 \\
\hline $\begin{array}{l}\text { Simple payback } \\
\text { period }(\mathrm{PB})\end{array}$ & & $\square$ & $\square$ & $\square$ & $\square$ & $\begin{array}{l}\text { Adjusted present } \\
\text { value (APV) }\end{array}$ & $\square$ & $\square$ & & & $\square$ \\
\hline $\begin{array}{l}\text { Discounted } \\
\text { payback period } \\
(\mathrm{DPB})\end{array}$ & $\square$ & $\square$ & $\square$ & $\square$ & $\square$ & $\begin{array}{l}\text { Profitability index } \\
\text { (PI) }\end{array}$ & $\square$ & $\square$ & $\square$ & & $\square$ \\
\hline $\begin{array}{l}\text { Accounting rate } \\
\text { of return (ARR) }\end{array}$ & $\square$ & $\square$ & $\square$ & $\square$ & $\square$ & Real option theory & $\square$ & $\square$ & $\square$ & L & $\square$ \\
\hline $\begin{array}{l}\text { Net present } \\
\text { value (NPV) }\end{array}$ & $\square$ & $\square$ & $\square$ & $\square$ & $\square$ & $\begin{array}{l}\text { Game theory } \\
\text { decision }\end{array}$ & $\square$ & $\square$ & $\square$ & L & $\square$ \\
\hline $\begin{array}{l}\text { Internal rate } \\
\text { of return (IRR) }\end{array}$ & $\square$ & $\square$ & $\square$ & $\square$ & $\square$ & $\begin{array}{l}\text { Non financial } \\
\text { decision rules } \\
\text { (please specify): }\end{array}$ & $\square$ & $\square$ & $\square$ & $\square$ & $\square$ \\
\hline $\begin{array}{l}\text { Modified internal } \\
\text { rate of return } \\
(\text { MIRR) }\end{array}$ & $\square$ & $\square$ & $\square$ & $\square$ & $\square$ & & & & & & \\
\hline
\end{tabular}

Please state if you use any other methods: 
Please specify the relative usage of various supplementary capital budgeting methods/tools for incorporating risk and uncertainties $(1=$ never, $2=$ rarely, $3=$ sometimes, $4=$ often, $5=$ Always)

\begin{tabular}{|c|c|c|c|c|c|c|c|c|c|c|}
\hline $\begin{array}{l}\text { Capital budgeting } \\
\text { methods }\end{array}$ & 12 & 3 & 4 & 5 & $\begin{array}{l}\text { Capital budgeting } \\
\text { methods }\end{array}$ & 1 & 2 & 3 & 4 & 5 \\
\hline $\begin{array}{l}\text { Sensitivity } \\
\text { analysis/Break } \\
\text { even }\end{array}$ & $\square \square$ & & $\square$ & $\square$ & $\begin{array}{l}\text { Market value } \\
\text { added }\end{array}$ & $\square$ & $\square$ & & $\square$ & I \\
\hline Scenario analysis & $\square \square$ & $\sqcup$ & $\square$ & $\square$ & $\begin{array}{l}\text { Complex } \\
\text { mathematical } \\
\text { model }\end{array}$ & $\square$ & $\square$ & $\square$ & $\square$ & $\square$ \\
\hline $\begin{array}{l}\text { Monte Carlo } \\
\text { simulations }\end{array}$ & $\square \square$ & $\square$ & $\square$ & $\square$ & $\begin{array}{l}\text { Linear } \\
\text { programming }\end{array}$ & $\square$ & $\square$ & $\square$ & 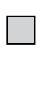 & $\square$ \\
\hline Decision trees & $\square \square$ & $\square$ & $\square$ & $\square$ & $\begin{array}{l}\text { Shorter payback } \\
\text { period (Adjusting } \\
\text { the payback } \\
\text { period) }\end{array}$ & $\square$ & $\square$ & $\square$ & L & $\square$ \\
\hline $\begin{array}{l}\text { High cut off } \\
\text { rates }\end{array}$ & $\square \square$ & $\square$ & $\square$ & $\square$ & $\begin{array}{l}\text { Use of certainty } \\
\text { equivalents instead } \\
\text { of expected } \\
\text { cash flows }\end{array}$ & $\square$ & $\square$ & $\square$ & ᄂ & $\square$ \\
\hline $\begin{array}{l}\text { Uncertainty } \\
\text { absorption in } \\
\text { cash flows }\end{array}$ & $\square \square$ & L & $\square$ & $\square$ & Probability analysis & $\square$ & $\square$ & ${ }^{-}$ & L & $\square$ \\
\hline $\begin{array}{l}\text { Adjusting the } \\
\text { required return }\end{array}$ & $\square \square$ & L & $\square$ & $\square$ & & & & & & \\
\hline $\begin{array}{l}\text { Inflation adjusted } \\
\text { cash flows }\end{array}$ & $\square \square$ & L & $\square$ & $\square$ & & & & & & \\
\hline
\end{tabular}

4. Others (please specify): 